\title{
Developing refutation text to resolve students' misconceptions in addition and subtraction of integers
}

\author{
Syarifah Fadillah, Utin Desy Susiaty ${ }^{1}$
}

\begin{abstract}
Abstrak: Miskonsepsi siswa dalam penjumlahan dan pengurangan bilangan bulat perlu diatasi karena materi ini merupakan prasyarat bagi siswa untuk mempelajari materi matematika lanjutan seperti aljabar. Kesalahan dalam memahami konsep prasyarat akan menghambat penerimaan dan integrasi pengetahuan baru. Penelitian ini bertujuan mengembangkan media pembelajaran refutation text untuk mengatasi miskonsepsi siswa dalam penjumlahan dan pengurangan bilangan bulat. Refutation text yang dikembangkan berbentuk Lembar Kerja Siswa (LKS) dengan merujuk pada model pengembangan Borg dan Gall (1983). Uji coba refutation text dilakukan pada 15 orang siswa SMP kelas VII. Hasil penelitian menunjukkan bahwa (1) hasil penilaian ahli menunjukkan refutation text layak digunakan sebagai media pembelajaran bagi guru dalam mengajarkan penjumlahan dan pengurangan bilangan bulat; (2) refutation text yang diterapkan di kelas uji coba efektif dalam mengatasi miskonsepsi siswa dalam penjumlahan dan pengurangan bilangan bulat; dan (3) hasil penilaian praktisi dan respon siswa menunjukkan bahwa refutation text praktis digunakan sebagai media pembelajaran untuk mengatasi miskonsepsi siswa. Dalam hal ini, refutation text yang dikembangkan membantu siswa memperbaiki kesalahan konsep pada materi penjumlahan dan pengurangan bilangan bulat dan bisa digunakan oleh guru di kelas. Namun, refutation text tersebut perlu dikembangkan untuk mengantisipasi kesalahan siswa dalam mengintepretasi soal cerita dengan menyediakan beberapa kemungkinan kesalahan intepretasi dan perbaikan.
\end{abstract}

Kata kunci: Miskonsepsi, Refutation text, Bilangan bulat

\begin{abstract}
Students' misconceptions in addition and subtraction of integers need to be addressed since this topic is a prerequisite for students to learn advanced mathematics topics such as algebra. Having misconceptions in understanding the prerequisite concepts will hamper the acquisition and integration of new knowledge. The purpose of this study was to develop refutation text to resolve the misconception of students in addition and subtraction of integers. Refutation text was developed in the form of student worksheet adopting the development model from Borg and Gall (1983). Tryout of refutation text involved fifteen seventh-grade students. The study found that (1) The experts' validation reveals that refutation text is suitable to be used as learning media for students on addition and subtraction of integers; (2) The refutation text implemented in the tryout was useful to resolve students' misconception in addition and subtraction of integers; and (3) The practitioner's assessment and students' response showed that refutation text is practical. Drawing from the findings, we argue that the developed refutation text help students correcting their misconceptions in the topics and could be used by the teachers in the classroom practices. However, the refutation text needs to be extended to anticipate students' mistake in interpreting word problems by providing some possible mistakes and its correction.
\end{abstract}

Keywords: Misconceptions, Refutation text, Integers

\footnotetext{
${ }^{1}$ IKIP PGRI Pontianak, West Kalimantan, Indonesia, syffadillah@gmail.com 


\section{A. Introduction}

Misconception is often used to refer to a belief that lacks agreement with presently common scientific description (Tippet, 2010). Other terms occasionally contain alternative belief, alternative framework, alternative conception, children's sciences, inaccurate concept, intuitive conception, inaccurate prerequisite knowledge, non-scientific concept, preconception, and preteaching conception (Chinn \& Malhotra, 2002; Guzzetti, Williams, Skeels \& Wu, 1997). Misconceptions will interrupt the acquisition of new knowledge because misconceptions in understanding the prerequisite concept are believed to hold back the new knowledge acquisition and integration (Gollub, Bertenthal, Labov, \& Curtis, 2002).

Before students learn a new concept, it is important for students to correct their misconceptions on the concepts underlying the new concepts that will be learned. It is also essential for the teacher to distinguish whether students have misconceptions or not understanding the concept. The distinction will differ in handling the lesson. Students with misconceptions offer a teacher some benefits to decide whether they are correct or incorrect by pointing out their misconception from one concept to another. Students' awareness of their misunderstanding is the foundation to check their misconceptions. It is necessary to re-teach students with misconception to understanding the concept correctly.

Integer operation is an important concept in mathematics learning in lower secondary school. Yet, many students still have misconceptions in doing integer operations. Bishop, Lamb, Philipp, Whitacre, Schappelle, and Lewis (2014) argue that the notion of negative numbers and operations with integers have conceptual difficulties. These difficulties, in Vlassis' (2001) view, influence negatively students' learning on several crucial algebraic concepts like algebraic equations and expressions. Integer operation is often considered an easy or trivial material by some students. In fact, in solving this problem students remain making any misconceptions since the teacher was less inculcating the correct concept into the students.

Makonye and Hantibi (2014) explained students' misconceptions: (1) The misconceptions of over generalization. It was visible within the learners' responses to questions $27-29$, two students answered 2. For $-65+45$, students got 110 or -110 . Students' faulty conception is that subtraction is commutative; (2) The misconceptions of interference. It was turned into obvious in the learners' answers to questions wherein they had been required to multiply; $(-2 x-4)$ or to divide $(-25 \div-5)$. Some students in such conditions did not do multiplication or division, they added and subtracted alternatively. The misconception could be related to the formerly learned skill, i.e., addition and subtraction, interfered with the new skill (multiplication and division); and (3) The misconception of meaning. Students could not understand having a two or a threetermed final answer. They 'completed' it using a one-value answer.

Students' misconceptions in understanding a concept need to be corrected. To do so, the students are suggested to find out the way and the cause of their incorrect work. When the students understand their misconception, they will not repeat the same mistakes to the next question. Refutation text becomes an alternative method to solve students' misconceptions for its provision of an explicit statement on commonly embraced misconception followed by a direct refutation of the misconception. A refutation text first exposes the statement of the misconception explicitly and then provides the correct concept.

A refutation text is one of the gaining knowledge of media that permits to triumph over students' misconception. This text type, called a refutational text, is a text structure that confront readers' misconceptions (Tippet, 2010). Refutation text has two components, i.e., the assertion 
of a commonly containing misconception and an explicit refutation of that misconception emphasizing on the presently recognized scientific clarification. A refutation text rebuts scientific misconceptions and explains the normative idea that may be useful strategies for resolving misconceptions and influencing conceptual change (Nussbaum, Cordova, \& Rehmat, 2017).

Tippet (2010) proposes some contributing factors that make studying refutation texts a practical approach to facilitate conceptual change. The factors cover incorrect prior knowledge, the presentation of information in a reasonable and coherent way, and the nature of the presented information. Furthermore, another strength of a refutation text, as claimed by Sinatra and Broughton (2011), is that readers who pursue to grasp refutation text through the mechanisms of maintaining coherence or undertaking cognitive struggle are likely to have both comprehension and conceptual transformation. Therefore, greater integration of study and instructional practices in these two areas is likely to advance both scientific literacy and comprehension growth.

This study aimed to develop refutation text to resolve the misconception of lower secondary students in the operation of addition and subtraction of integers. A refutation text was developed through analyzing what misconceptions experienced by the students in the operation of addition and subtraction of integers, and then continued with refutation text design, validation, and implementation in the tryout class. Refutation text was given to students who experience misconceptions to be studied independently under the guidance of the teacher.

\section{B. Methods}

In accordance with the aim, this study proceeded under research and development approach ( R \& D) which primes to develop refutation text for addition and subtraction of integers. The development of refutation text incorporated the development model from Borg and Gall (Gall, Gall, and Borg, 1983). Borg and Gall's model comprises ten major steps. However, the 10-step procedure was adapted and modified into seven steps for adjustment to the real condition in the field and for reason of practically. The number of research subjects is small so it does not require limited tryout. The tryout process for using refutation text was only done once.

The seven-steps procedure as follow: First, needs analysis. Preliminary study found that students needed learning tools to overcome misconception about addition and subtraction of integers. Second, planning preliminary form of product. It includes defining skills, stating objectives and determining course sequence. Third, designing refutation text. Fourth, assessment (validation) of the refutation text by the experts. Fifth, revisions which refer to the validation results. Sixth, tryout of the refutation text which involved seventh-grade students. And seventh, the revision of refutation text based on the results of tryout.

The validation of each aspect on refutation text and final test was analyzed with a Likert scale, that is, very feasible, feasible, quite feasible, and less feasible. Very feasible is scored 4, feasible 3 , quite feasible 2, and less feasible 1 . The next step was calculating the average score on each aspect of the assessments from all members of expert and the average scores were categorized as in Table 1.

The tryout inolved the seventh-grade students. We distributed a preliminary test to thirtyseven students to determine students' misconceptions in addition and subtraction of integers. The test consisted of 10 questions about: (1) adding and subtracting positive and negative integers, (2) adding and subtracting positive integers, (3) adding and subtracting negative integers, and (4) solve the addition and reduction integer word problems. From the results of the 
preliminary test, we interviewed seventeen students who were suspected of having misconceptions. From the results of the interview, we decided to provide refutation text to the fifteen students who experienced misconceptions.

Table 1. The Assessment of refutation text

\begin{tabular}{cc}
\hline Average score $(\overline{\boldsymbol{x}})$ & Category \\
\hline $3.25<\bar{x} \leq 4$ & very feasible \\
$2.50<\bar{x} \leq 3.25$ & feasible \\
$1.75<\bar{x} \leq 2.50$ & quite feasible \\
$1.75<\bar{x} \leq 1$ & less feasible \\
\hline
\end{tabular}

After students taught with refutatiton text, we determined the effectiveness of refutation text in overcoming student misconceptions in addition and subtraction of integers, by giving a final test. The test was similar to the prelimanary test. The refutation text is called to be effective to overcome student's misconception in addition and subtraction of integers if all students who experience misconception in the preliminary test, do not experience misconceptions in solving the final test number 1 to 8 which relate to basic addition and substraction of integers.

The tryout of the refutation text was also to identify the practicality of refutation text. Practicality relates to the ease of use of the refutation text. Practicality data was obtained through a questionnaire filled by a practitioner (teacher in the tryout classroom) and fifteen students who were taught using refutation text. The assessment of each aspect on quiestionnare was analyzed with a Likert scale, that is, very practical, practical, quite practical, and less practical. Very practical is scored 4, practical 3, quite practical 2, and less practical 1. The next step was calculating the average score on each aspect of the assessments and the average scores were categorized as in Table 2.

Table 2. The practicality of refutation text

\begin{tabular}{cc}
\hline Average score $(\overline{\boldsymbol{x}})$ & Category \\
\hline $3.25<\bar{x} \leq 4$ & very practical \\
$2.50<\bar{x} \leq 3.25$ & practical \\
$1.75<\bar{x} \leq 2.50$ & quite practical \\
$1.75<\bar{x} \leq 1$ & less practical \\
\hline
\end{tabular}

\section{Findings and Discussion}

The description of the results of this study is divided into four parts, namely (1) needs analysis and design of refutation text, (2) validity of refutation text, (3) effectiveness of refutation text, and (4) practicality of refutation text

\section{Needs analysis and design of refutation text}

The first step in the development of refutation text was to analyze the needs of learning media in order to achieve the learning objectives. In analyzing the need to develop a learning media, systematic process is needed to examine the goals to achieve and associated with the characteristics of students who would use the learning media. The need analysis and 
characteristics of the students were obtained by interviewing the mathematics teachers at the target school. We also observed the classroom learning and gave a preliminary test on the topic of addition and subtraction of integers. The preliminary test was given to find out what misconceptions held by students in solving the problem of addition and subtraction of integers.

The interview with the mathematics teachers showed that students make many misconceptions in the addition and subtraction of integers even though the ability to solve these basic arithmetics is one of the competencies that should be mastered by the seventh-grade students. The misconception resulted from the students' not fully comprehending well how to proceed integer operation. In this case, it is necessary for the students to have learning media that can overcome misconception of students in addition and subtraction of integers.

As for the preliminary test given to the students, it is was found that there are some misconceptions such as in (1) adding and subtracting positive and negative integers and (2) adding and subtracting negative integers. This misconception resulted from their misconception of proceeding integers' addition and addition using number lines. These findings are consistent with the research of Tyas and Amin (2017) which uncovered that one of the students' misconception in integer operations is to subtract negative integers as in $-3-15=-12$ and $-3-15$ $=12$.

Another mistake found in the preliminary test is that students misunderstand word problems, which results in students' erroneously determining the strategy in solving the problems. Figure 1 is an example of students' mistake in solving the following problems:

The temperature in the refrigerator $-9^{\circ} \mathrm{C}$. After switching off, the temperature rises to

$4^{\circ} \mathrm{C}$. What is the temperature of the refrigerator after it is turned off?

\begin{tabular}{|c|c|}
\hline Diketahuí & Suhu kulkas mula-mula: $-9^{\circ} \mathrm{C}$ \\
\hline & Suhu akhir kullcas $=4^{\circ} \mathrm{C}$ \\
\hline Ditinya & Suhu kulkas setetah dimatihon \\
\hline Jawab & $40-\left(-9^{\circ}\right)=130 \mathrm{C}$ \\
\hline
\end{tabular}

Figure 1. Students' mistake in interpreting word problem

The similar mistake was also found by Setyawati and Indiati (2018) that students had difficulty in understanding problems involving integer addition and subtraction operations.

In more detail, the students' characteristics revealed that in one side the students' ability in mathematics was classified below average, and in the other side the motivation of students in learning mathematics was low. These analyses of students' misconception in integer operation and of the students' characteristics underlay a reference in the preparation of refutation text so that by this media the students can easily grasp the contents of refutation text and are interested in reading and solving the problems in the student worksheet.

The next step was to design the product. The product design followed the flow of student worksheet refutation text: (1) determining title and designing cover of student worksheet, (2) making table of contents, (3) writing basic competence, (4) listing description of learning topics, (5) making samples of problems accompanied with possible misconception made by students in solving the problems and correct solutions to solving the problems, and (6) making practice questions. 
The refutation text first shows what mistakes students can possibly make in solving problems and explains the causes of these mistakes. Next, the correct answers are presented along with an explanation of the operating steps in the number line. The concepts that needed confirmation were written in bright color (yellow) in the form of callouts in order to be eye-catching, attractive and focal point of students' attention to recall.

The following is an example of refutation text that resulted from this study.

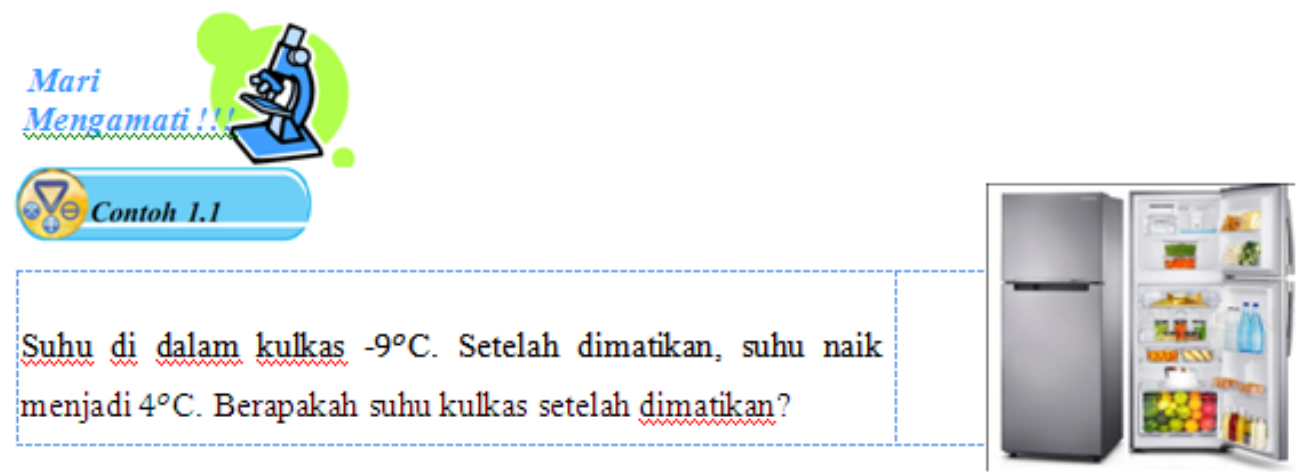

\section{Catatan:}

Hati-hati dalam memahami soal seperti ini, biasanva sering terjadi kesalahan-kesalahan seperti:

$4-9=-5$

Kesalahan seperti ini karena kamu salah dalam memahami soal.

$-9+4=13$

$-9+4=-13$

$-9+4=5$

Kesalahan ini karena kamu belum memahami operasi penjumlahan bilangan bulat

Figure 2. Statement of the misconception

Jawab:

Secara sistematis soal tersebut dapat dinyatakan dengan $-9+4=\ldots$

Dengan menggunakan garis bilangan, langkah-langkahnya sebagai berikut:

1. Dari angka 0 bergerak 9 satuan ke kiri (arah negatif) sampai pada angka -9

Jika penjumlahan dengan lawan bilamgan maka dikurangkan (berbalik arah)

2. Dari angka -9 bergerak 4 satuan ke kanan (arah positif) sampai pada angka -5

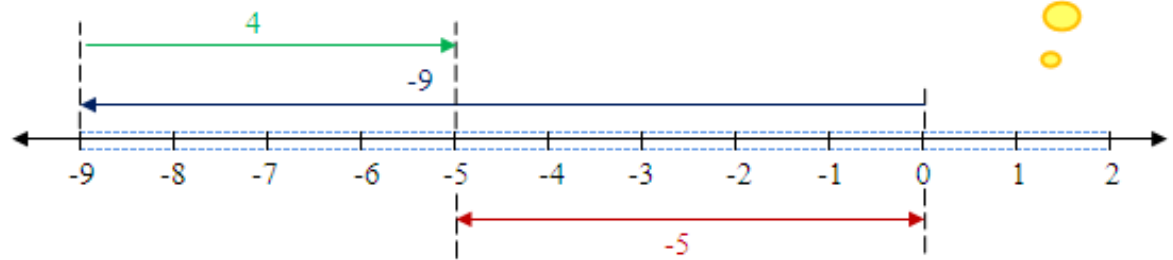

Jadi, suhu kulkas setelah dimatikan adalah -5

Figure 3. The correct concept 


\section{Validity of refutation text}

The experts' validation was useful to make improvements to the initial design prior to tryout. Three validators assessed the validation of the initial design. Table 3 shows the results of the first-stage validation.

Table 3. Experts validation results in first stage

\begin{tabular}{|c|c|c|c|c|c|}
\hline Aspect & Item & Criteria & Expert 1 & Expert 2 & Expert 3 \\
\hline \multirow[t]{3}{*}{ Content } & 1 & $\begin{array}{l}\text { The suitability of the } \\
\text { content of refutation text } \\
\text { with basic competence } \\
\text { and learning objectives }\end{array}$ & $\begin{array}{c}\text { less } \\
\text { feasible }\end{array}$ & feasible & very feasible \\
\hline & 2 & $\begin{array}{l}\text { The clarity of incorrect } \\
\text { and correct concept on } \\
\text { refutation text }\end{array}$ & $\begin{array}{c}\text { quite } \\
\text { feasible }\end{array}$ & feasible & feasible \\
\hline & 3 & $\begin{array}{l}\text { Formulation of questions } \\
\text { and examples already in } \\
\text { accordance with the } \\
\text { topics }\end{array}$ & feasible & feasible & feasible \\
\hline \multirow[t]{3}{*}{ Presentation } & 4 & Systematic & feasible & feasible & feasible \\
\hline & 5 & Interesting & feasible & $\begin{array}{l}\text { quite } \\
\text { feasible }\end{array}$ & quite feasible \\
\hline & 6 & $\begin{array}{l}\text { The clarity of the pictures } \\
\text { or illustrations }\end{array}$ & feasible & feasible & feasible \\
\hline \multirow[t]{2}{*}{ Languange } & 7 & $\begin{array}{l}\text { The contents of the } \\
\text { refutation text in } \\
\text { accordance with EYD } \\
\text { (Official Indonesian } \\
\text { Spelling System) }\end{array}$ & feasible & feasible & very feasible \\
\hline & 8 & $\begin{array}{l}\text { The use of } \\
\text { communicative words }\end{array}$ & $\begin{array}{l}\text { quite } \\
\text { feasible }\end{array}$ & $\begin{array}{c}\text { very } \\
\text { feasible }\end{array}$ & feasible \\
\hline
\end{tabular}

Following up the first assessment, we revised the initial design of refutation text. The revisions include: (1) making the appearance on the student worksheet layout more interesting by adding relevant images and colors to the subtitles of student worksheet, (2) completing the basic competencies by adding learning objectives, (3) changing the language in the refutation text into more communicative language in order the students are more interested in reading it, and (4) adding some explanations about the students' misconception to provide them with better understanding of their misconception.

After the initial refutation text design was revised, the second validation was assessed by the experts. The result of the validation assessment in the second stage is shown in Table 4.

Table 4. Expert validation results in second stage

\begin{tabular}{cclccc}
\hline Aspect & Item & \multicolumn{1}{c}{ Criteria } & Expert 1 & Expert 2 & Expert 3 \\
\hline Content & 1 & $\begin{array}{l}\text { The suitability of the } \\
\text { content of refutation text } \\
\text { with basic competence } \\
\text { and learning objectives }\end{array}$ & very feasible & feasible & very feasible \\
& & & \\
\end{tabular}




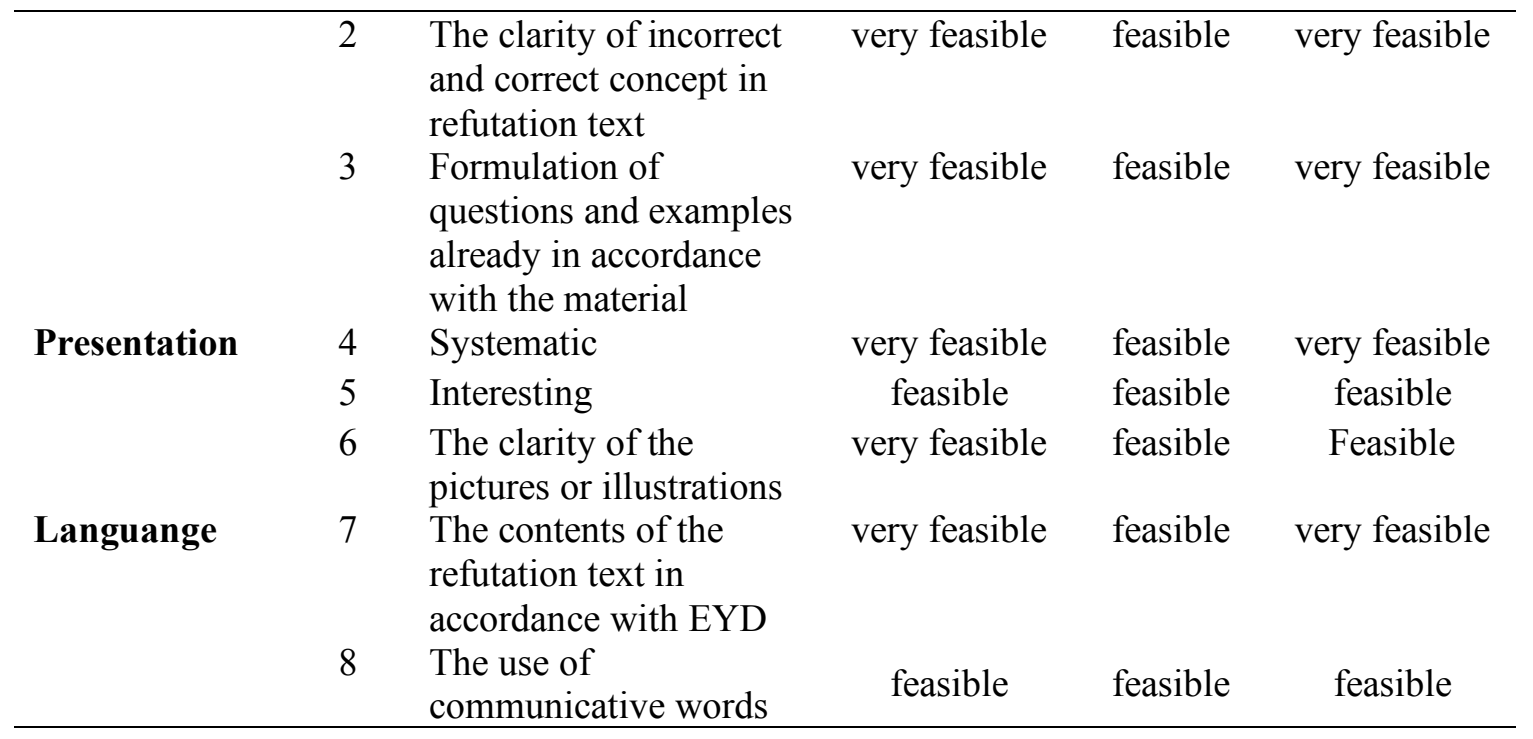

On the second stage assessment, the expert team assessed the refutation text as feasible and highly feasible meaning that the revised refutation text was feasible for the tryout.

\section{Effectiveness of refutation text}

The tryout of the revised refutation text involved fifteen students who experienced misconceptions. The product was tested to identify the effectiveness of refutation text. As for the preliminary test given to the students, it is found fifteen students had misconceptions. There are some misconceptions the students have such as the misconception in (1) adding and subtracting positive and negative integers, (2) adding and subtracting negative and negative integers, and (3) solve the addition and reduction integer word problems. We found some misconceptions made by seventh-grade students; $4+(-3)=7, \quad-4+(-3)=-1,-8-(6)=2,4$ $-(-5)=-1$, and $-3-(-2)=1$.

After the students were given treatment by using refutation text, a final test on adding and subtracting of integers was given to the students. Students works on the test after using the refutation text indicated that misconceptions about the addition and reduction of integers material can be resolved. The fifteen students had no misconceptions in solving problem 1 to 8 . However, five students still experienced mistake in intepreting word problems.

Figure 4 is one example of students' answer on the preliminary test and the final test. All students have been able to answer correctly for eight questions from ten questions given. Two other questions are word problems, five students still experienced mistake on one of the two questions. They made mistake in intepreting the word problems. Figure 5 is an example of students' mistake in solving the problems on the final test. The problem was as follow,

The multi-storey building consists of 20 floors. A man was originally on the 5th floor because there were items left behind, he went down 3 floors. Then he climbed another 8 floors to meet his friend. What's on the floor of the man now?

Students works on the final test indicated the effectiveness of the use of refutation text to overcome student's misconception in addition and subtraction of integers. This finding was consistent with the study piloted by Lem, Onghena, Verschaffel, and Dooren (2017). They found that students who learn with refutation text scored better on a box plot interpretation test than 
students being exposed to an instructional text in which no misconceptions were explicitly revealed or refuted.

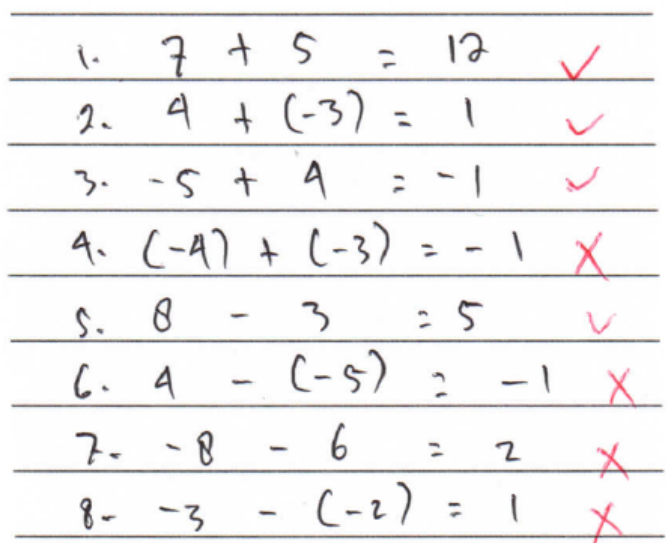

(a)

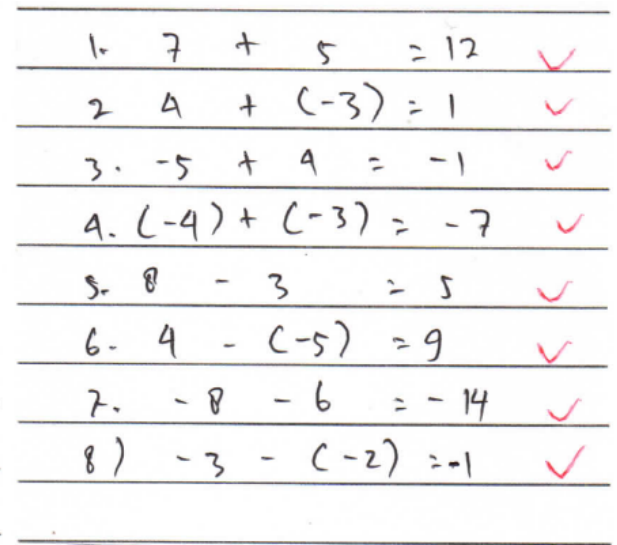

(b)

Figure 4. A student's answers on the preliminary test (a) and the final test (b)

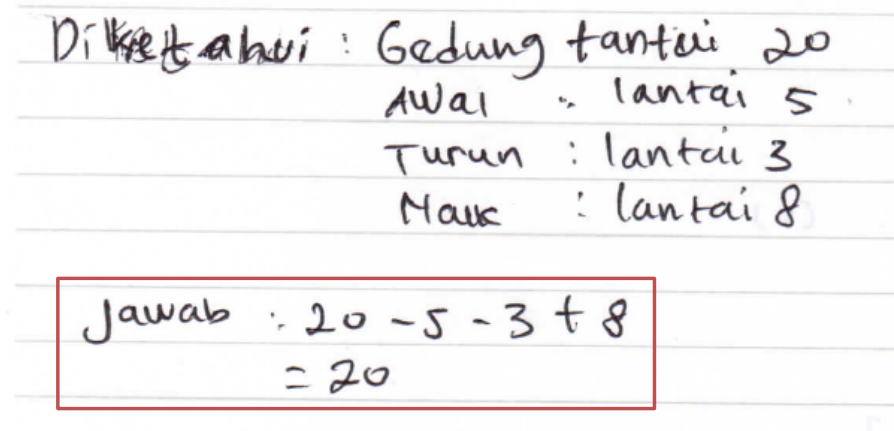

Figure 5. Students' mistake in interpreting a word problem on the final test

Learning by using refutation text makes students aware of the misconception when confronted with a text containing frequent errors. Additionally, when they learn the text with the correct concept, there will be a conceptual change to the students. We found this from the results of the interview with several students who experienced misconceptions. This is in line with Sinatra and Broughton (2011) assert that conceptual change is most possibly to happen when the student's misconception is triggered at the same time as the scientific explanation. A confrontation of the misconception and the scientific explanation give the reader the chance to combine two conceptions. It may also promote profound engagement with those contrasting perspectives and thereby raise the possibility of conceptual change.

Students' works on the final test also showed five students' mistake in interpreting word problems. This mistake still occurred because of the lack of explanation in refutation text about what mistakes might exist when students solve the word problems. The observation on the tryout process and the results of students work on the final test indicated that product revision was still necessary. This product revision was made to produce a better one. Therefore, some examples of mathematical problems solving were added into the refutation text. The students' possible 
mistake in understanding problem was described and the correct understanding of the problems solving was also provided. The confrontation between wrong understanding and correct understanding of mathematical problem solving is expected to make students better understand the problem.

Observing students' learning during the tryout, we found deficiencies in the refutation text, such as the necessity for affirmation on the concepts that are often misconceived. The concepts that needed confirmation were written in bright color in the form of callouts in order to be an eye-catching, attractive and focal point of students' attention to recall. In addition, emphasis on misconceptions can also be made when teachers teach. Lem, Onghena, Verschaffel, and Dooren (2017) assert that refutation can also be utilized into the teacher's instructional behavior, without the written texts used. In this case, the teacher can use more emphasis, intonation, or repetition to give the refutation even more powerful point than learners just read a text.

\section{Practicality of refutation text}

Practicality relates to the ease of use of the refutation text. Practicality data was obtained through a questionnaire filled by a practitioner (teacher on tryout classroom) and fifteen students. Both the teacher and the students' used refutation text in the tryout class. The result of the teacher's assessment on the practicality of refutation text is shown in Table 5. The teacher's average response is 3.5 categorised as very practical. Table 6 shows the students' responses on the practicality of refutation text. The average response is 3,325 in a very practical category. Both of the responses show that the developed refutation text is pratical in use to help teachers overcome student's misconception.

Table 5. Teacher's assessment about practicality of refutation text

\begin{tabular}{|c|c|c|c|}
\hline Item & Indicator & Value & Criteria \\
\hline 1 & $\begin{array}{l}\text { The refutation text is easy to use in } \\
\text { accordance with the wishes of users }\end{array}$ & 4 & very practical \\
\hline 2 & $\begin{array}{l}\text { The refutation text is designed } \\
\text { according to student's } \\
\text { misconception in addition and } \\
\text { subtraction of integers }\end{array}$ & 4 & very practical \\
\hline 3 & $\begin{array}{l}\text { The use of the refutation text can } \\
\text { generate student's interest in } \\
\text { learning }\end{array}$ & 3 & practical \\
\hline 4 & $\begin{array}{l}\text { Learning by using this refutation } \\
\text { text makes students more quickly } \\
\text { to understand their misconception }\end{array}$ & 4 & very practical \\
\hline 5 & $\begin{array}{l}\text { Using this refutation text can save } \\
\text { the teacher's time and energy to } \\
\text { overcome students' misconception }\end{array}$ & 3 & practical \\
\hline 6 & $\begin{array}{l}\text { The refutation text can be } \\
\text { interpreted by the teacher }\end{array}$ & 4 & very practical \\
\hline 7 & $\begin{array}{l}\text { Using refutation text can make } \\
\text { learning more interesting }\end{array}$ & 3 & practical \\
\hline 8 & $\begin{array}{l}\text { The refutation text can be used as a } \\
\text { means of self-learning }\end{array}$ & 3 & practical \\
\hline
\end{tabular}


Table 6. Students' response about practicality of refutation text

\begin{tabular}{clcc}
\hline Item & \multicolumn{1}{c}{ Indicator } & Average & Criteria \\
\hline 1 & $\begin{array}{l}\text { Learning by using this refutation } \\
\text { text makes me more quickly to } \\
\text { understand my misconception }\end{array}$ & 3,20 & practical \\
2 & $\begin{array}{l}\text { Learning by using this refutation } \\
\text { text can help me learn } \\
\text { independently }\end{array}$ & 3,27 & very practical \\
3 & $\begin{array}{l}\text { Explanation/ drawing /table in the } \\
\text { refutation text make it easier to } \\
\text { understand the notion of addition }\end{array}$ & 3,27 & very practical \\
4 & $\begin{array}{l}\text { and subtraction of integers } \\
\text { Refutation text makes me more }\end{array}$ & 3,67 & very practical \\
5 & $\begin{array}{l}\text { active in learning } \\
\text { It is easy to understand the } \\
\text { language used in this refutation } \\
\text { text }\end{array}$ & 3,33 & very practical \\
6 & $\begin{array}{l}\text { Using this refutation text make } \\
\text { learning more interesting }\end{array}$ & 3,33 & very practical \\
7 & $\begin{array}{l}\text { Refutation text help me to easily } \\
\text { understand the mathematics topics }\end{array}$ & 3,20 & practical \\
8 & $\begin{array}{l}\text { Refutation text motivates me to } \\
\text { learn mathematics }\end{array}$ & 3,33 & very practical \\
\hline
\end{tabular}

This study involved only fifteen students who experienced misconceptions in addition and subtraction of integers. The subjects and one teacher were not significant to assess the practicality of a product. However, these results have at least provided an initial description of the practicality of the refutation text developed. In this case, future research should use more subjects or practitioners to test the effectiveness and practicality of refutation text to resolve students' misconceptions.

\section{Conclusion}

The current study developed refutation text in teaching and learning on addition and subtraction of integers. The experts' validation showed that the media is suitable for intensive learning. Refutation text enables to resolve the students' misconception on addition and subtraction of integers because the students had no misconceptions in solving basic problems on addition and subtraction of integers. Refutation text becomes an alternative tool to solve students' misconceptions for its provision of an explicit statement on commonly embraced misconception followed by a direct refutation of the misconception. However, some students made mistakes in interpreting the word problems. In this case, some examples of mathematical problems solving were added into the refutation text. The confrontation between wrong and correct understanding of mathematical problem solving is expected to make students better understand the problem. This study implies the necessary to develop refutation text on other mathematics topics to lessen misconception.

\section{Acknowledgment}

We thank IKIP PGRI Pontianak for indispensable aid to fund this research under grant number 001/L.202.103/PDK/III/2017. 


\section{References}

Bishop, J. P., Lamb, L. L., Philipp, R. A., Whitacre, I., Schappelle, B. P., \& Lewis, M. L. (2014). Obstacles and affordances for integer reasoning: An analysis of children's thinking and the history of mathematics. Journal for Research in Mathematics Education, 45(1), 19-61.

Chinn, C., \& Malhotra, B. (2002). Children's responses to anomalous scientific data: How is conceptual change impeded? Journal of Educational Psychology, 94(2), 327-343. Doi:10.1037/00220663.94.2.327.

Lem, S., Onghena, P., Verschaffel, L., \& Dooren, W.F. (2017). Using refutational text in mathematics education. ZDM Mathematics Education, 49(4), 509-518. Doi:10.1007/s11858-017-0843-y.

Gall, M, D., Gall, J. P., \& Borg, W. R. (1983). Educational research an introduction third edition. USA: Pearson Education.

Gollub, J.P., Bertenthal, M.W., Labov, J.B., \& Curtis, P.C. (2002). Learning and understanding improving advanced study of mathematics and science in US high schools. Washington: National Academy Press.

Guzzetti, B., Williams, W., Skeels, S., \& Wu, S. (1997). Influence of text structure on learning counterintuitive physics concepts. Journal of Research in Science Teaching, 34(7), 701-719.

Makonye, J \& Hantibi, N. (2014). Exploration of grade 9 learners' errors on operations with directed numbers. Mediterranean Journal of Social Sciences. 5(20), 1564-1572. Doi:10.5901/mjss.2014.v5n20p1564.

Nussbaum, E.M., Cordova, J.R., \& Rehmat, A.P. (2017). Refutation texts for effective climate change education. Journal of Geoscience Education, 65(1), 23-34. Doi:10.5408/15-109.1.

Setyawati, R.D. \& Indiati, I. (2018). Analysis misconception of integers in microteaching activities. IOP conference series: Journal of Physics: Conference Series 1013 (2018) 012146. Doi:10.1088/17426596/1013/1/012146.

Sinatra, G.M. \& Broughton, S.H. (2011). Bridging reading comprehension and conceptual change in science education: The promise of refutation text. Reading Research Quarterly, 46(4), 374-393. Doi: 10.1002/RRQ.005.

Tippett, C.D. (2010). Refutation text in science education: A review of two decades of research. International Journal of Science and Mathematics Education, 8(6), 951-970.

Tyas, N.E.N. \& Amin, S. M. (2017). Profil miskonsepsi siswa pada materi bilangan bulat berdasarkan tingkat kecerdasan logis matematis siswa. Jurnal Ilmiah Pendidikan Matematika, 2(6), 311-319.

Vlassis, J. (2001). Solving equations with negatives or crossing the formalizing gap. Proceedings of The Twenty-fifth International Conference for the Psychology of Mathematics Education, 4, 375-382. Utrecht, Netherlands. 


\section{Appendix 1}

English translation of the figures

Given : Initial temperature of the refrigerator $=-9^{\circ} \mathrm{C}$

The final temperature of the refrigerator $=4^{\circ} \mathrm{C}$

Asked : $\quad$ The temperature of the refrigerator after turning off?

Solution : $\quad 4^{\circ} \mathrm{C}-\left(-9^{\circ} \mathrm{C}\right)=13^{\circ} \mathrm{C}$

So, the temperature of the refrigerator after turning off was $13^{\circ} \mathrm{C}$

Figure 1. Students' mistake in problem solving

Let's observe!!!

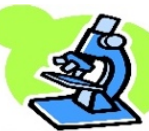

Example 1.1

The refrigerator's temperature is $-9^{\circ} \mathrm{C}$. After switching off, the temperature rised to $4^{\circ} \mathrm{C}$. What is the temperature of the refrigerator after it is turned off?

Note:

Be careful in understanding the questions, errors often occur such as:

$>\quad 4-9=-5$

Errors because you misunderstood the problem

$>-9+4=13$

$-9+4=-13$

$-9+4=5$

Errors because you misunderstood in integer addition operation

Figure 2. Statement of misconception 


\section{Solution:}

Systematically the problem can be expressed as $-9+4=\ldots$.

By using a number line, the steps are as follows:

1. From 0 moves 9 units to the left (negative direction) until reaching -9

2. From -9 moves 4 units to the right (positive direction) until reaching -5

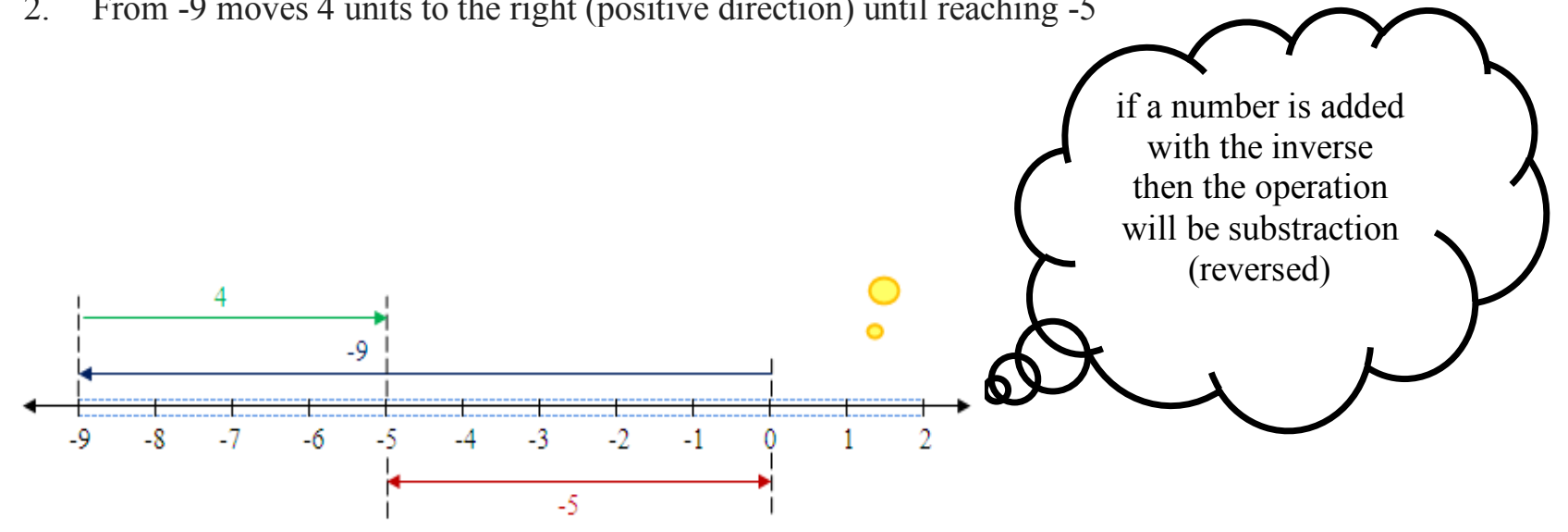

So, the temperature of the refrigerator after it is turned off was -5 .

Figure 3. The correct concept

Given: The building is 20 floors

First position: 5 th floor

Down: 3rd floor

$\mathrm{U}: 8$ th floor

Solution: $20-5-3+8$

$=20$

Figure 5. Students' mistake in interpreting a word problem on the final test 